\title{
Anaerobic Codigestion of Sugarcane Press Mud with Food Waste: Effects on Hydrolysis Stage, Methane Yield, and Synergistic Effects
}

\author{
Lina M. Cárdenas-Cleves, Luis F. Marmolejo-Rebellón, and Patricia Torres-Lozada \\ Environmental Pollution Study and Control-ECCA Research Group, Faculty of Engineering, Universidad del Valle, \\ Cali 760032, Colombia
}

Correspondence should be addressed to Patricia Torres-Lozada; patricia.torres@correounivalle.edu.co

Received 12 February 2018; Revised 7 July 2018; Accepted 15 July 2018; Published 15 August 2018

Academic Editor: Konstantinos E. Kakosimos

Copyright (c) 2018 Lina M. Cárdenas-Cleves et al. This is an open access article distributed under the Creative Commons Attribution License, which permits unrestricted use, distribution, and reproduction in any medium, provided the original work is properly cited.

\begin{abstract}
Sugarcane press mud (SPM) has a high potential to produce renewable energy through anaerobic digestion (AD); however, hydrolysis is the limiting stage of the process due to the presence of slowly biodegradable compounds. An alternative that can improve this deficiency is anaerobic codigestion (AcoD). In this investigation, the monodigestion of SPM and its AcoD with food waste (FW) were evaluated through the biochemical methane potential (BMP) test, and kinetic parameters were analyzed through the analysis of the kinetic models of first order and modified Gompertz. This study showed that the AcoD of SPM with FW improved the hydrolysis stage, increased methane $\left(\mathrm{CH}_{4}\right)$ yield, improved the stability of the process, and presented synergistic effects. As regards the hydrolysis stage, the hydrolysis constant was increased, and the lag phase was reduced. The monodigestion of SPM (SPM : FW $100: 0$ ) showed an increase of $9 \%$ with the addition of external nutrients solution, while that of AcoD in the SPM :FW 80:20 ratio showed the highest $\mathrm{CH}_{4}$ yield, with increments of 12 and $22 \%$ in comparison with the monodigestion of SPM under WN and NN conditions, respectively. It is even possible to add up to $40 \%$ of FW (SPM: FW 60 : 40 ) and achieve an increase of 5\% compared to the monodigestion of SPM under the NN condition. The synergistic effects obtained in this study showed that the incorporation of FW, in the substrates ratios evaluated, would improve the AD of the SPM without addition of external nutrients solution, which represents economic and environmental benefits of implementing this alternative at full scale.
\end{abstract}

\section{Introduction}

According to FAO [1], in 2016 approximately 1.9 million tons of cane were generated, which were used mainly for the production of sugar, Brazil, India, and China being the largest world producers. On the sugar production process from sugarcane, different by-products are generated, among which the sugarcane press mud (SPM) stands out, which is produced in the clarification and filtration of the juice. On average, between 28 and $45 \mathrm{~kg}$ of SPM per ton of cut cane can be generated [2], which are generally arranged in the soil or applied to cane crops, due to their high content of nutrients, mainly nitrogen $[3,4]$. However, these practices can affect soil porosity, generate bad odours, and contaminate water sources due to the presence of fats and organic compounds in the SPM.

The general composition of the SPM demonstrates its potential for the production of renewable energy through anaerobic digestion $(\mathrm{AD})[5,6]$; however, being formed by a lignocellulosic structure, avoids the solubilisation of nutrients for absorption by microorganisms [7] and affects its degradability, being the hydrolysis the limiting stage [8]. To solve this problem, physical, mechanical, and chemical pretreatments and combinations of these have been carried out; however, they are costly alternatives that require specialized equipment and qualified personnel or can generate toxic by-products [9]. A more sustainable strategy to improve the hydrolysis of SPM is the use of anaerobic 
codigestion (AcoD), due to the synergistic effect caused by the addition of a cosubstrate with complementary characteristics [10].

In the case of SPM, residues with a high content of organic matter of rapid degradation such as food waste (FW) can be used [11], which are generated in significant quantities, and can represent the largest component of the municipal solid waste, reaching up to $50 \%$ in developed countries and between 50 and $75 \%$ in developing countries $[12,13]$. Additionally, more than $95 \%$ of these wastes ends at landfills, where they become materials with a high polluting potential $[14,15]$. Despite the advantages the AcoD of SPM with FW, problems of inhibition and organic overload can affect the hydrolysis stage and the methane $\left(\mathrm{CH}_{4}\right)$ yield, for which it is important to define the most adequate substrate ratios on the process. Thus, in this study, the AcoD of SPM with FW was evaluated, analyzing the effects on the hydrolysis stage, $\mathrm{CH}_{4}$ yield, and synergistic effects.

\section{Materials and Methods}

2.1. Characterization of Substrates and Inoculum. Sugarcane press mud (SPM) was provided by a sugar mill located in Cauca state (Colombia). The food waste (FW) was formed from the wastes of the restaurant of the Universidad del Valle (Cali-Colombia), considering the physical composition and the physicochemical characteristics of the unprocessed FW generated in a city that carries out source separation and selective collection [16]. These wastes were crushed mechanically in order to obtain a particle size less than or equal to $10 \mathrm{~mm}$ [17].

The inoculum used was sludge from the anaerobic digester of a municipal wastewater treatment plant (WWTP) (Cali-Colombia), which operates with complete mixing at $35^{\circ} \mathrm{C}[18]$.

2.2. Analytical Methods. Both substrates were characterized according to the following parameters: moisture (\%), $\mathrm{pH}$ (units), total alkalinity (TA) and bicarbonate alkalinity (BA) $\left(\mathrm{g} \mathrm{CaCO}_{3} \mathrm{~L}^{-1}\right)$, volatile fatty acids (VFAs) (g HAc L $\left.{ }^{-1}\right)$, chemical oxygen demand (COD): total and filtered $\left(\mathrm{g} \mathrm{O}_{2}\right.$ $\left.\mathrm{L}^{-1}\right)$, total solids (TS) $\left(\mathrm{g} \mathrm{L}^{-1}\right)$, volatile solids (VS) $\left(\mathrm{g} \mathrm{L}^{-1}\right)$, total organic carbon (TOC) $\left(\mathrm{g} \mathrm{L}^{-1}\right)$, total nitrogen (TN) (g $\left.\mathrm{L}^{-1}\right)$, total phosphorus (TP) $\left(\mathrm{g} \mathrm{L}^{-1}\right)$, lignin (\%), raw fibre (\%), and cellulose (\%) $[19,20]$. Characterization of inoculum was carried out by measuring $\mathrm{pH}, \mathrm{TA}, \mathrm{BA}, \mathrm{VFAs}, \mathrm{TS}$, and VS [20]. The specific methanogenic activity (SMA) $\left(\mathrm{g} \cdot \mathrm{DQO} \mathrm{CH}_{4}\right.$ $(\mathrm{g} \text { VSS } \mathrm{d})^{-1}$ ) was also determined in accordance with that recommended by Soto et al. [21].

2.3. Biochemical Methane Potential (BMP) Tests. The reactor of the OxiTop ${ }^{\circledR}$ system (WTW, Giessen, Germany) was used, with a working volume of $200 \mathrm{~mL}$ and headspace of $50 \mathrm{~mL}$ for the storage of $\mathrm{CH}_{4}$ generated, which was measured directly by capturing $\mathrm{CO}_{2}$ with the addition of $4 \mathrm{NaOH}$ pellets to each reactor, considering previous studies [22].

The BMP tests were performed at the mesophilic temperature, guaranteeing $35 \pm 0.1^{\circ} \mathrm{C}$ in the WTW TS 606-G/2-i incubator (WTW, Giessen, Germany); the $\mathrm{pH}$ was adjusted to 7 units with sodium bicarbonate solution $\left(\mathrm{NaHCO}_{3}\right)$ (4\%); and the agitation was manual and intermittent and was performed 3 times per day before measuring the pressure. The incubation time was 30 days from which it was observed that the $\mathrm{CH}_{4}$ yield stabilized because the pressure did not vary more than $5 \mathrm{HPa}[23]$.

In BMP tests, a control (inoculum and distilled water) was included in order to determine $\mathrm{CH}_{4}$ generated by the residual organic matter present in the inoculum and by the endogenous metabolism, whose value was subtracted from the $\mathrm{CH}_{4}$ yield of each reactor. The volume of $\mathrm{CH}_{4}$ at standard conditions was determined by the equations suggested by Cárdenas-Cleves et al. [24]. The BMP tests was carried out in triplicate, the substrate/inoculum $(S / I)$ ratio was $1 \mathrm{~g}$ $\mathrm{VS}_{\text {Substrate }} / \mathrm{g} \mathrm{VS}_{\text {Inoculum }}$ [25], and the fixed inoculum concentration $\left.(I)\left(1.5 \mathrm{~g} \mathrm{VS} \mathrm{L}^{-1}\right)\right)$ [21] and the concentrations of the substrates $(S)$ were varied in terms of VS. In the condition with nutrients (WN), the solution recommended by Angelidaki et al. [26] and Cárdenas-Cleves et al. [24] was used.

2.4. AcoD of SPM with FW: Effects on Hydrolysis Stage, Methane Yield, Stability of the Process, and Synergistic Effects. The AcoD of SPM with FW without addition of nutrients (NN) was evaluated in three SPM : FW ratios $(80: 20,60: 40$, and $50: 50$ ), and the monodigestion of SPM (with-WN and without addition of nutrients solution- NN) and FW (NN) was evaluated as controls, as shown in Table 1.

To evaluate the effect on the hydrolysis stage, the firstorder kinetic model and modified Gompertz model were used, as shown in the following equations $[13,27]$ :

$$
\begin{aligned}
& \mathrm{BMP}=\mathrm{BMP}_{\max }\left(1-e^{-k_{\mathrm{h}} t}\right), \\
& \mathrm{BMP}=\mathrm{BMP}_{\text {max }} e\left\{-e\left[\frac{R_{\text {max }} e}{\mathrm{BMP}_{\max }}(\lambda-t)+1\right]\right\},
\end{aligned}
$$

where BMP is the biochemical potential of the $\mathrm{CH}_{4}$ accumulated during the test $\left(\mathrm{mL} \mathrm{CH} \mathrm{CVS}_{4}^{-1}\right), \mathrm{BMP}_{\max }$ is the potential maximum $\mathrm{CH}_{4}$ yield when the time tends to infinity $\left(\mathrm{mL} \mathrm{CH}_{4} \mathrm{~g} \mathrm{VS}^{-1}\right), k_{\mathrm{h}}$ is the first-order hydrolysis constant $\left(\mathrm{d}^{-1}\right), t$ is the test time $(\mathrm{d}), R_{\max }$ is the maximum rate of the $\mathrm{CH}_{4}$ yield $\left(\mathrm{mL} \mathrm{CH} \mathrm{CH}^{-1} \mathrm{~g} \mathrm{VS}^{-1}\right), \lambda$ is the lag phase $(\mathrm{d})$, and $e$ is the exponential value of 1 that corresponds to 2.718 .

For the estimation of the values in the first-order kinetic model equations $\left(\mathrm{BMP}_{\max }\right.$ and $\left.k_{\mathrm{h}}\right)$ and the modified Gompertz model equations $\left(\mathrm{BMP}_{\max }, R_{\max }\right.$, and $\left.\lambda\right)$, the experimental data of the mean BMP and the time for each reactor were used, for which a nonlinear regression was obtained using the Levenberg-Marquardt algorithm in R software i386 3.4.2 (R Foundation ${ }^{\circledR}$ ). To verify the adjustment of the data to the models, the coefficient of determination $\left(R^{2}\right)$ and mean squared error (MSE) were determined, as recommended by Kafle and Kim [28].

To assess the influence of the substrate ratio on the response variable (BMP), analysis of variance (ANOVA) and Tukey's tests $(p<0.05)$ were performed, using $\mathrm{R}$ software 
TABLE 1: SPM : FW ratios evaluated in each reactor.

\begin{tabular}{|c|c|c|c|c|c|}
\hline \multirow{2}{*}{ Reactor } & \multicolumn{2}{|c|}{ SPM } & \multicolumn{2}{|c|}{ FW } & \multirow{2}{*}{$\begin{array}{c}\mathrm{I} \\
\left(\mathrm{g} \mathrm{VS} \mathrm{L}^{-1}\right)\end{array}$} \\
\hline & (\%) & $\left(\right.$ g VS L $\left.^{-1}\right)$ & $(\%)$ & $\left(\mathrm{g} \mathrm{VS} \mathrm{L}^{-1}\right)$ & \\
\hline 1 & 100 & 1.50 & 0 & 0 & 1.50 \\
\hline 2 & 80 & 1.20 & 20 & 0.30 & 1.50 \\
\hline 3 & 60 & 0.90 & 40 & 0.60 & 1.50 \\
\hline 4 & 50 & 0.75 & 50 & 0.75 & 1.50 \\
\hline 5 & 0 & 0 & 100 & 1.50 & 1.50 \\
\hline
\end{tabular}

TABLE 2: Physicochemical characterization of substrates and inoculum.

\begin{tabular}{|c|c|c|c|c|}
\hline Parameter & Unit & Sugarcane press mud (SPM)* & Food waste $(\mathrm{FW})^{*}$ & Inoculum* \\
\hline Moisture $\left(n_{\mathrm{SPM}, \mathrm{FW}, \mathrm{I}}: 4\right)$ & $\%$ & $70.30 \pm 1.80$ & $78.53 \pm 6.18$ & ND \\
\hline $\mathrm{pH}\left(n_{\mathrm{SPM}, \mathrm{FW}, \mathrm{I}}: 4\right)$ & Unit & 5.37 & 5.17 & 7.16 \\
\hline $\mathrm{TA}\left(n_{\mathrm{SPM}, \mathrm{FW}, \mathrm{I}}: 4\right)$ & $\mathrm{g} \mathrm{CaCO}_{3} \mathrm{~L}^{-1}$ & $3.88 \pm 0.93$ & $4.21 \pm 3.44$ & $4.22 \pm 0.83$ \\
\hline $\mathrm{BA}\left(n_{\mathrm{SPM}, \mathrm{FW}, \mathrm{I}}: 4\right)$ & $\mathrm{g} \mathrm{CaCO}_{3} \mathrm{~L}^{-1}$ & - & - & $2.42 \pm 0.30$ \\
\hline VFAs $\left(n_{\mathrm{SPM}, \mathrm{FW}, \mathrm{I}}: 4\right)$ & $\mathrm{g} \mathrm{HAc} \mathrm{L}^{-1}$ & $6.45 \pm 0.11$ & $3.65 \pm 0.23$ & $1.54 \pm 0.04$ \\
\hline $\mathrm{COD}_{\text {Total }}\left(n_{\mathrm{SPM}, \mathrm{FW}, \mathrm{I}}: 4\right)$ & $\mathrm{g} \mathrm{O}_{2} \mathrm{~L}^{-1}$ & $152.33 \pm 0.94$ & $80.41 \pm 8.84$ & ND \\
\hline $\mathrm{COD}_{\text {Filtered }}\left(n_{\mathrm{SPM}, \mathrm{FW}, \mathrm{I}}: 4\right)$ & $\mathrm{g} \mathrm{O}_{2} \mathrm{~L}^{-1}$ & $36.40 \pm 1.41$ & $22.03 \pm 2.01$ & ND \\
\hline TS $\left(n_{\mathrm{SPM}, \mathrm{FW}, \mathrm{I}}: 4\right)$ & $\mathrm{g} \mathrm{L}^{-1}$ & $132.05 \pm 0.42$ & $88.31 \pm 6.45$ & $56.98 \pm 0.53$ \\
\hline VS $\left(n_{\mathrm{SPM}, \mathrm{FW}, \mathrm{I}}: 4\right)$ & $\mathrm{g} \mathrm{L}^{-1}$ & $84.42 \pm 0.53$ & $81.06 \pm 6.95$ & $27.55 \pm 0.21$ \\
\hline $\operatorname{COT}^{\mathrm{a}}\left(n_{\mathrm{SPM}}: 2 ; n_{\mathrm{FW}}: 4\right)$ & $\mathrm{g} \mathrm{L}^{-1}$ & 1083.86 & $481.71 \pm 77.08$ & ND \\
\hline $\mathrm{TN}^{\mathrm{a}}\left(n_{\mathrm{SPM}}: 2 ; n_{\mathrm{FW}}: 4\right)$ & $\mathrm{g} \mathrm{L}^{-1}$ & 47.79 & $15.25 \pm 0.18$ & ND \\
\hline $\mathrm{TP}\left(n_{\mathrm{SPM}}: 2 ; n_{\mathrm{FW}}: 4\right)$ & $\mathrm{g} \mathrm{L}^{-1}$ & 14.26 & $0.14 \pm 0.02$ & ND \\
\hline $\operatorname{Lignin}\left(n_{\mathrm{SPM}}: 2 ; n_{\mathrm{FW}}: 4\right)$ & $\%$ & 5.50 & 2.97 & ND \\
\hline Raw fibre $^{\mathrm{a}}\left(n_{\mathrm{SPM}}: 2 ; n_{\mathrm{FW}}: 4\right)$ & $\%$ & 24.57 & $10.64 \pm 0.78$ & ND \\
\hline Cellulose $^{\mathrm{a}}\left(n_{\mathrm{SPM}}: 2 ; n_{\mathrm{FW}}: 4\right)$ & $\%$ & 16.01 & $16.12 \pm 10.30$ & ND \\
\hline $\operatorname{SMA}\left(n_{\mathrm{I}}: 4\right)$ & $\mathrm{g} \mathrm{DQO}_{\mathrm{CH}_{4}}(\mathrm{~g} \mathrm{VSS} \mathrm{d})^{-1}$ & ND & ND & 0.008 \\
\hline
\end{tabular}

*Average values \pm SD (standard deviation). ${ }^{2}$ Dry basis; $n$ : number of samples; ND: not determined.

i386 3.4.2 (R Foundation). The control parameters that were measured at the end of each test were $\mathrm{pH}, \mathrm{TA}$, and BA. Furthermore, the alpha index $(\alpha)$ that corresponded to the $\mathrm{BA}$ and TA ratio was calculated to analyze the stability of the process [29]. The analysis of the occurrence of synergistic effects was determined according to the following equation:

$$
\mathrm{BMP}_{\mathrm{W}}=\mathrm{BMP}_{\mathrm{SPM}} * \% \mathrm{SPM}+\mathrm{BMP}_{\mathrm{FW}} * \% \mathrm{FW},
$$

where $\mathrm{BMP}_{\mathrm{W}}$ is the weighted biochemical methane potential $\left(\mathrm{mL} \mathrm{CH}_{4} \mathrm{~g} \mathrm{VS}^{-1}\right), \mathrm{BMP}_{\mathrm{SPM}}$ is the experimental biochemical methane potential obtained in the AD of SPM (SPM : FW $100: 0$ ratio) $\left(\mathrm{mL} \mathrm{CH}_{4} \mathrm{~g} \mathrm{VS}^{-1}\right), \% \mathrm{SPM}$ is the SPM percentage in the ratio, $\mathrm{BMP}_{\mathrm{FW}}$ is the experimental biochemical methane potential obtained in the AD of FW (SPM : FW $0: 100$ ratio) $\left(\mathrm{mL} \mathrm{CH}_{4} \mathrm{~g} \mathrm{VS}^{-1}\right)$, and $\% \mathrm{FW}$ is the $\mathrm{FW}$ percentage in the ratio.

When the difference $\left(\mathrm{BMP}-\mathrm{BMP}_{\mathrm{W}}\right)$ was positive and higher than the BMP value considering the standard deviation, a synergistic effect $(S)$ occurs; otherwise, the effect is antagonistic (A) [25].

\section{Results and Discussion}

3.1. Characterization of Substrates and Inoculum. Table 2 presents the results of the physicochemical characterization of the substrates and inoculum.
Table 2 shows that sugarcane press mud (SPM) presented a high moisture content that is around $70 \%$. The $\mathrm{pH}$ (5.37 units) was lower than that reported by Rouf et al. [5] and Nyonje et al. [6] (7.5 units) and equal to that obtained by Bohórquez et al. [30] (5.4 units); this difference can be associated with the juice clarification process, which also affects the value of the TA [4].

The $\mathrm{COD}_{\text {Total }}$, TS, and VS showed the presence of a high content of organic matter found mainly in particulate form $\left(\mathrm{COD}_{\text {Filtered }} / \mathrm{COD}_{\text {Total }}\right.$ of 0.24$)$ as reported by LópezGonzález et al. [2]. The $C / N$ ratio was 22.68 , which is close to the lower limit of the range recommended by Lee et al. [31] (20-35). The content of TP is high $\left(\mathrm{COD}_{\text {Total }}\right.$ : TN : TP ratio of $350: 36.8: 32.8)$ due to the phosphate fertilization of the cane crops and the addition of phosphates to accelerate the clarification of the juice. The presence of micronutrients in the SPM is derived partially from the particles adhered to the cane and the chemical inputs used during the clarification of the juice, such as coagulants, flocculants, and lime. The lignin and cellulose content was similar to that reported by Rouf et al. [5] and may be due to the addition of fine particles of bagasse that is used to improve the filtration of the clarified sludge that forms the SPM [3].

As regards the FW, they also had a high moisture content due to the predominance of vegetables and fruits $[16,32]$. These residues are easily degradable, which favors the 


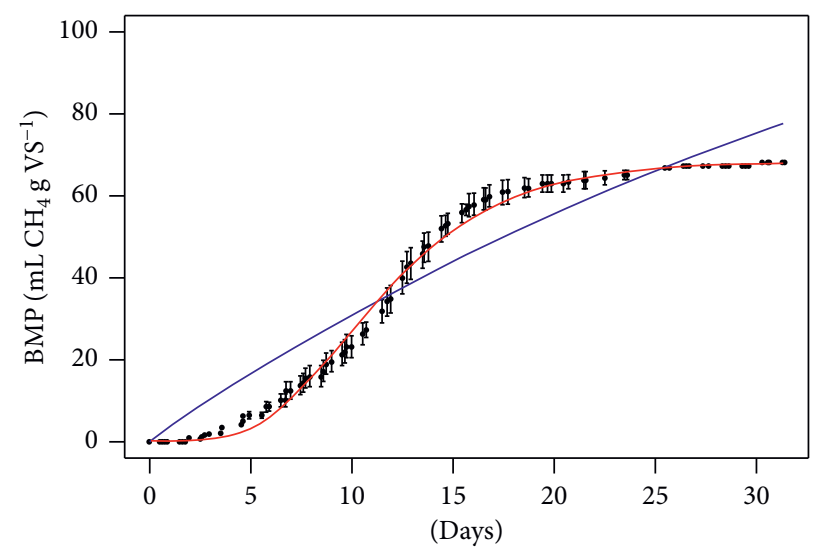

(a)

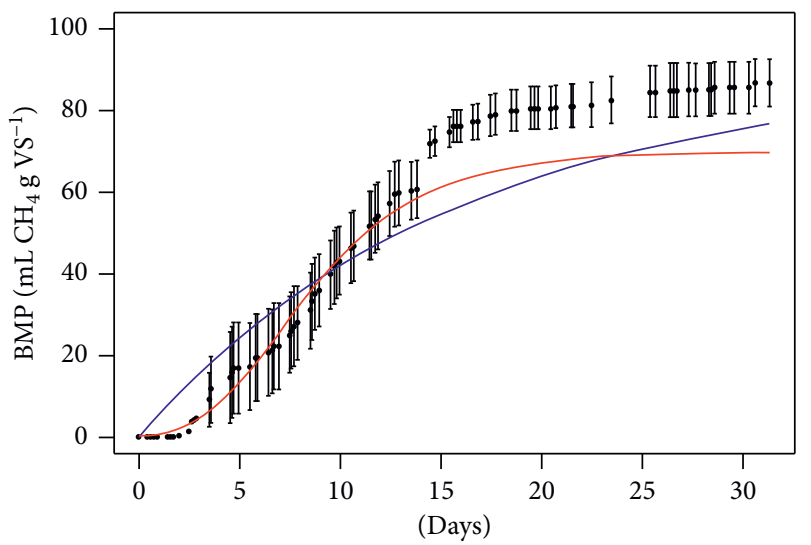

(c)

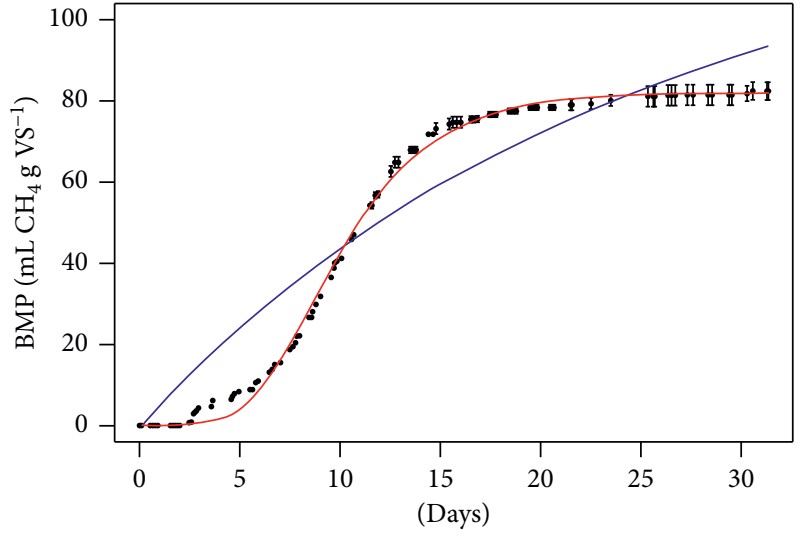

(b)

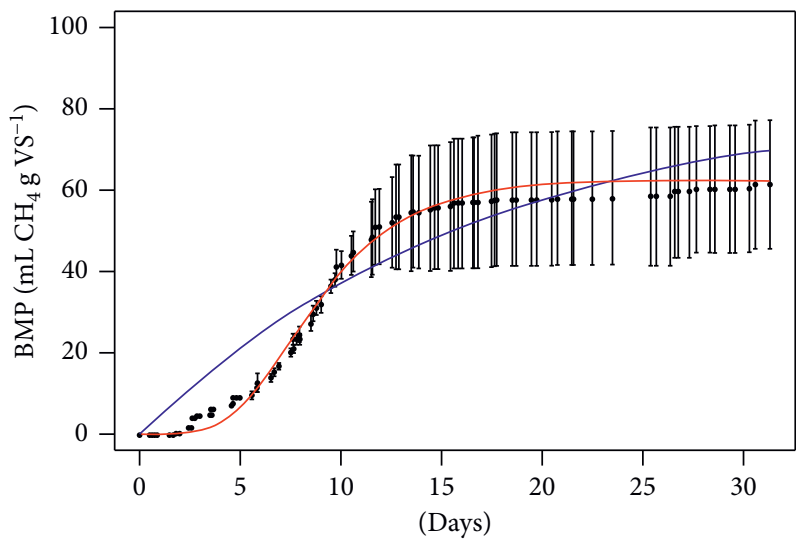

(d)

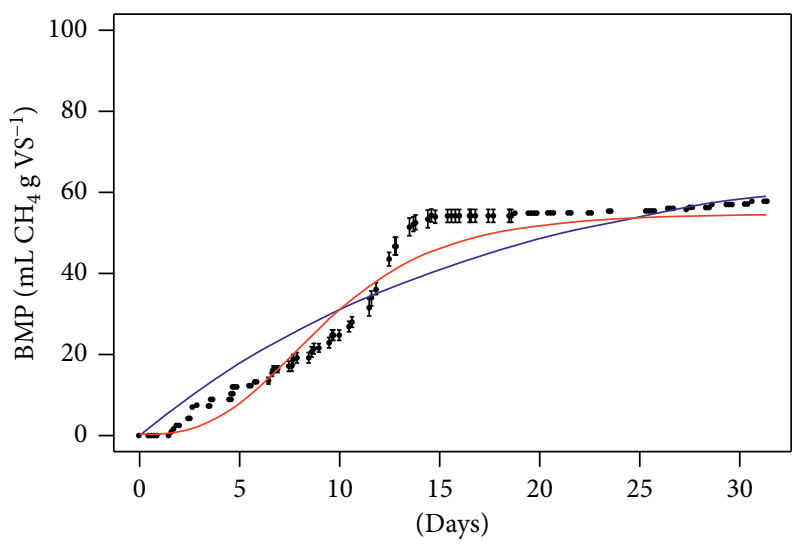

(e)

FIGURE 1: BMP of each SPM:FW ratio: (a) $100: 0$; (b) $80: 20$; (c) $60: 40$; (d) 50:50; (e) $0: 100$, and best fit to the first-order kinetic model (blue line) and the modified Gompertz model (red line). The error bars represent the experimental standard deviation between triplicates $(n=15)$.

formation and accumulation of VFAs $[33,34]$, whose value was close to $4 \mathrm{~g} \mathrm{~L}^{-1}$, concentration from which may generate mild inhibition in the process according to Wang et al. [35]. These values coincide with a low $\mathrm{pH}$ (5.17) and absence of BA.

The values obtained for the $\mathrm{COD}_{\text {Total }}$, TS, and VS show that the FW is characterized by having a high content of organic matter that is in particulate form $\left(\mathrm{COD}_{\text {Filtered }} / \mathrm{COD}_{\text {Total }}: 0.30\right)$. Regarding nutrient content, the $\mathrm{COD}_{\text {Total }}: \mathrm{TN}: \mathrm{TP}$ ratio $(350: 5.43: 0.59)$ showed phosphorus deficiency, which is a predominant element in the SPM, whereas the $C / N$ ratio (31.58) was found in the recommended range (20-35) [31], and given its greater concentration, the contribution that FW can make to balance this ratio in the AcoD is evident. Finally, the cellulose content was found in the range reported by Fisgativa et al. [36] and is related to the presence of fruits and vegetables, as well as the presence of crude fibre. 
TABLE 3: Kinetic parameters for each SPM : FW ratio.

\begin{tabular}{|c|c|c|c|c|c|c|c|c|c|}
\hline \multirow{2}{*}{ SPM : FW ratio } & \multicolumn{4}{|c|}{ First-order kinetics model } & \multicolumn{5}{|c|}{ Modified Gompertz model } \\
\hline & $\mathrm{BMP}_{\max }$ & $k_{\mathrm{h}}\left(\mathrm{d}^{-1}\right)$ & $R^{2}$ & MSE & $\mathrm{BMP}_{\max }$ & $R_{\max }$ & $\lambda(\mathrm{d})$ & $R^{2}$ & MSE \\
\hline $100: 0$ & $154.10 \pm 33.50$ & $0.022 \pm 0.006$ & 0.910 & 62.01 & $68.40 \pm 0.49$ & $6.00 \pm 0.13$ & $5.52 \pm 0.12$ & 0.995 & 3.56 \\
\hline $80: 20$ & $128.60 \pm 14.31$ & $0.041 \pm 0.007$ & 0.897 & 108.24 & $81.98 \pm 0.38$ & $9.17 \pm 0.17$ & $5.28 \pm 0.08$ & 0.997 & 3.32 \\
\hline $60: 40$ & $88.49 \pm 4.28$ & $0.064 \pm 0.006$ & 0.936 & 41.82 & $69.79 \pm 0.44$ & $6.51 \pm 0.15$ & $3.06 \pm 0.13$ & 0.993 & 4.25 \\
\hline $50: 50$ & $82.96 \pm 5.38$ & $0.059 \pm 0.007$ & 0.910 & 52.43 & $62.40 \pm 0.32$ & $7.26 \pm 0.16$ & $4.31 \pm 0.10$ & 0.995 & 2.63 \\
\hline $0: 100$ & $70.89 \pm 4.94$ & $0.057 \pm 0.007$ & 0.901 & 39.66 & $54.46 \pm 0.80$ & $4.93 \pm 0.25$ & $3.62 \pm 0.28$ & 0.969 & 12.23 \\
\hline
\end{tabular}

$\mathrm{BMP}_{\max }\left(\mathrm{mL} \mathrm{CH}_{4} \mathrm{~g} \mathrm{VS}^{-1}\right) ; R_{\max }\left(\mathrm{mL} \mathrm{CH}_{4} \mathrm{~d}^{-1} \mathrm{~g} \mathrm{VS}^{-1}\right)$.

For the inoculum, the values of $\mathrm{pH}, \mathrm{TA}, \mathrm{BA}, \mathrm{VFAs}, \mathrm{TS}$, and VS were found among the characteristic ranges for sludge from anaerobic digesters of municipal WWTP $[18,37]$. The $\mathrm{pH}$ has a value close to neutrality, and the $\alpha$ index was 0.57 , indicating that the inoculum provides buffer capacity. The VS/TS ratio (0.48) and the SMA value indicate low inoculum activity compared to that reported by Angelidaki et al. [26].

\subsection{AcoD of SPM with FW: Effects on Hydrolysis Step, Methane} Yield, and Synergistic Effects. Figure 1 shows the BMP of each SPM : FW ratio and the best fit to the first-order kinetic model and the modified Gompertz model. In Table 3, the kinetic parameters for each model evaluated are presented.

Figure 1 and Table 3 show that, in general, the experimental results presented a better fit to the modified Gompertz model, which describes the $\mathrm{CH}_{4}$ yield with greater precision $\left(R^{2} \geq 0.97\right.$ and $\left.\mathrm{CME} \leq 12.23\right)$. As regards the firstorder kinetic model, although it is one of the most used because it provides useful information on the rate of degradation and the maximum $\mathrm{CH}_{4}$ yield [38], this study showed that it was not precise in the representation of the process because it does not consider the lag phase that was observed in all the curves [13].

In Table 4 , it is observed that the hydrolysis constant $\left(k_{\mathrm{h}}\right)$ of the SPM was lower than that of the FW, which could be due to the presence of de lignocellulosic compounds, evidenced in the characterization of SPM. In addition, the organic matter of the SPM is in an insoluble form, which affects the availability of the nutrients present in the substrate for the microorganisms and reduces the rate of degradation [39]. This also influenced the lag phase $(\lambda)$ because the SPM : FW 100:0 presented the longest lag phase $(\lambda)$, with values greater than 5 days. This study showed that the incorporation of FW in evaluated ratios increased the hydrolysis constant and reduced the lag phase.

As regards the methane yield, Figure 2 shows the BMP of the each SPM : FW ratio evaluated.

Figure 2 shows that the BMP of the SPM (SPM : FW 100:0) was higher than that of the FW (SPM : FW $0: 100$ ) because it has a higher content of organic matter and a balance of macronutrients such as TN and TP, as evidenced by the results of the characterization. The FW presented the lowest $\mathrm{BMP}$, which is associated with its low $\mathrm{pH}$, absence of bicarbonate alkalinity, accumulation of VFAs, and deficiency of nutrients as phosphorus according to the $\mathrm{COD}_{\text {Total }}$ : $\mathrm{TN}$ : TP ratio [40]. With respect to the $80: 20,60: 40$, and $50: 50$
TABLe 4: Parameters measured after the process.

\begin{tabular}{lccccc}
\hline $\begin{array}{l}\text { SPM }: \text { FW } \\
\text { ratio }\end{array}$ & $\begin{array}{c}\text { Nutrient } \\
\text { condition }\end{array}$ & $\mathrm{pH}$ & $\mathrm{AB}$ & $\mathrm{AT}$ & $\begin{array}{c}\alpha \\
\text { index }\end{array}$ \\
\hline $100: 0$ & $\mathrm{WN}$ & 7.62 & 334.56 & 483.39 & 0.69 \\
$100: 0$ & $\mathrm{NN}$ & 7.99 & 466.17 & 634.68 & 0.73 \\
$80: 20$ & $\mathrm{NN}$ & 7.77 & 408.36 & 515.37 & 0.79 \\
$60: 40$ & $\mathrm{NN}$ & 7.96 & 349.32 & 492.00 & 0.71 \\
$50: 50$ & $\mathrm{NN}$ & 8.03 & 397.29 & 537.51 & 0.74 \\
$0: 100$ & $\mathrm{NN}$ & 7.49 & 129.15 & 354.24 & 0.36 \\
\hline
\end{tabular}

pH (unit); $\mathrm{BA}$ and $\mathrm{TA}\left(\mathrm{mg} \mathrm{CaCO}_{3} \mathrm{~L}^{-1}\right)$; number of assays: 3 .

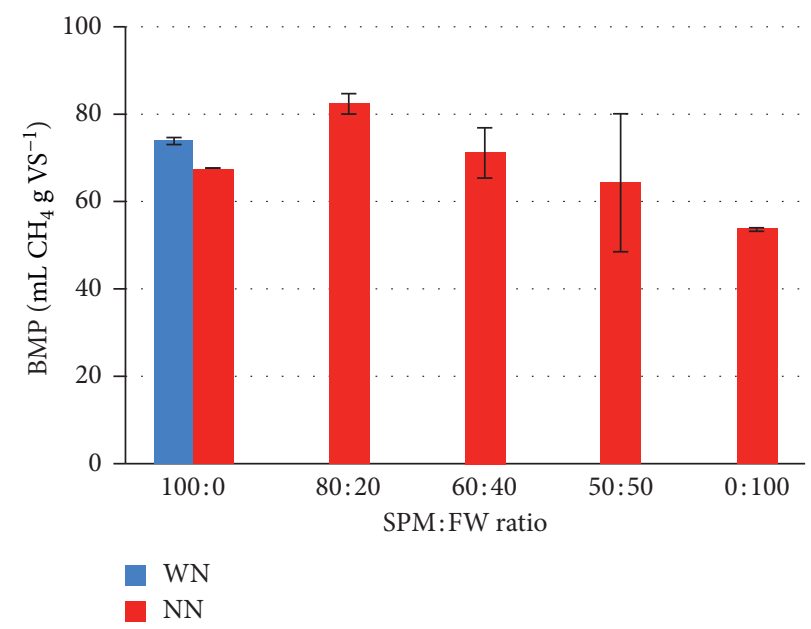

FIGURE 2: BMP for each SPM: FW ratio.

ratios, the ANOVA test $(p<0.05)$ indicated that there were no significant statistical differences between them.

Figure 2 also shows that, in the monodigestion of SPM (SPM : FW 100:0), an increase of 9\% was obtained when adding an external nutrients solution, while when incorporating FW under the NN condition (SPM : FW $80: 20$ ), increments of 12 and $22 \%$ were obtained with respect to the SPM :FW 100:0 under WN and NN conditions, respectively. It is even possible to add up to $40 \%$ of FW (SPM : FW 60:40) and achieve an increase of 5\% compared to the monodigestion of SPM under the NN condition. This showed that the AcoD allowed a balance of nutrients and suggests that it is possible to apply the AcoD without the addition of an external nutrients solution when using FW in such proportions, which is convenient due to mitigation of environmental impacts and cost reduction.

The stability of the process was determined by means of different control parameters shown in Table 4 . 
TABle 5: Synergistic effects of AcoD.

\begin{tabular}{|c|c|c|c|c|c|c|}
\hline SPM : FW ratio & $C / N$ ratio & BMP & SD & $\mathrm{BMP}_{\mathrm{W}}$ & Difference $\left(\mathrm{BMP}-\mathrm{BMP}_{\mathrm{W}}\right)$ & Effect \\
\hline $100: 0$ & 22.68 & 67.67 & 0.00 & 67.67 & 0.00 & - \\
\hline $80: 20$ & 24.46 & 82.36 & 2.34 & 64.85 & 17.51 & $\mathrm{~S}$ \\
\hline $60: 40$ & 26.24 & 71.12 & 5.75 & 62.04 & 9.09 & $S$ \\
\hline $50: 50$ & 27.13 & 64.29 & 15.79 & 60.63 & 3.66 & S \\
\hline $0: 100$ & 31.58 & 53.59 & 0.40 & 53.59 & 0.00 & - \\
\hline
\end{tabular}

$\mathrm{BMP}_{\mathrm{W}}$ : weighted biochemical methane potential $\left(\mathrm{mL} \mathrm{CH}_{4} \mathrm{~g} \mathrm{VS}^{-1}\right)$; $\mathrm{SD}$ : standard deviation; S: synergistic effect.

Table 4 shows that the lowest $\alpha$ index was obtained for SPM : FW 0:100 that presented the lowest BMP. It was also evidenced that the AcoD of SPM with FW increased the $\alpha$ index, being the best in the SPM:FW 80:20 in which the highest BMP was obtained, since adding a greater amount of FW a reduction in the BMP was observed. In SPM : FW $80: 20$, stable conditions were presented between the degradation of organic matter and VFA consumption by acetogenic microorganisms $[5,41]$.

The existence of synergistic effects $(S)$ was verified for each SPM : FW ratio, and the results are presented in Table 5.

Table 5 shows a favorable effect of AcoD of SPM with FW because in all the substrates ratios evaluated synergistic effects were observed, what was evidenced in the improvement of the hydrolysis and $\mathrm{CH}_{4}$ yield. The FW contributed with organic matter and balanced the $C / N$ ratio in the process, which coincides with that reported by Mahajan and Chopra [11] and Capson-Tojo et al. [42]. Additionally, the addition of FW would improve the AD of the SPM without addition of external nutrients solution.

\section{Conclusions}

Although the sugarcane press mud (SPM) has a high potential for use by anaerobic digestion (AD), the presence of lignocellulosic compounds affects the hydrolysis stage of the $\mathrm{AD}$ process. A strategy to improve this aspect is the anaerobic codigestion (AcoD) with food waste (FW), which provides organic matter and allows a balance in the $C / N$ ratio, even eliminating the use of an external nutrients solution.

This study showed that the AcoD of SPM with FW influenced the hydrolysis stage and $\mathrm{CH}_{4}$ yield stability of the process and presented synergetic effects. The AcoD increased the hydrolysis constant and reduced the lag phase. The monodigestion of SPM (SPM : FW $100: 0$ ) showed an increase of $9 \%$ with the addition of external nutrients solution, while with that AcoD in the SPM : FW 80:20 ratio, the highest $\mathrm{CH}_{4}$ yield was obtained, with increments of 12 and $22 \%$ under WN and NN conditions, respectively, in comparison with the monodigestion of SPM. It is even possible to add up to $40 \%$ of FW (SPM:FW 60:40) and achieve an increase of 5\% compared to the monodigestion of SPM under the NN condition. The stability of the process and the synergistic effects obtained in this study showed that the addition of FW in the substrates ratios evaluated would improve the $\mathrm{AD}$ of the SPM without addition of external nutrients solution, which represents economic and environmental benefits of implementing this alternative at full scale.

\section{Data Availability}

The data used to support the findings of this study are available from the corresponding author upon request.

\section{Conflicts of Interest}

The authors declare that they have no conflicts of interest.

\section{Acknowledgments}

The authors would like to thank the Universidad del Valle for the financial support of the project "Potencial de valorización energética y agrícola de la Fracción Orgánica de Residuos Sólidos Urbanos-FORSU” (C.I-2962).

\section{References}

[1] FAO: FAOSTAT-Statistics Division, Crops Statistics, Sugarcane, Food and Agriculture Organization of the United Nations, Rome, Italy, 2016.

[2] L. López, I. Pereda, J. Dewulf, J. Budde, M. Heiermann, and H. Vervaeren, "Effect of liquid hot water pre-treatment on sugarcane press mud methane yield," Bioresource Technology, vol. 169, pp. 284-290, 2014.

[3] N. Gupta, S. Tripathi, and C. Balomajumder, "Characterization of pressmud: a sugar industry waste," Fuel, vol. 90, no. 1, pp. 389-394, 2011.

[4] S. Kumar, R. Meena, D. Jinger, H. S. Jatav, and T. Banjara, "Use of pressmud compost for improving crop productivity and soil health," International Journal of Chemical Studies, vol. 5, no. 2, pp. 384-389, 2017.

[5] M. Rouf, P. Bajpai, and C. Jotshi, "Optimization of biogas generation from press mud in batch reactor," Bangladesh Journal of Scientific and Industrial Research, vol. 45, no. 4, pp. 371-376, 2010.

[6] E. Nyonje, P. Njogu, and R. Kinyua, "Assessment of the potential for utilization of sugarcane derived press mud for biogas generation in South Nyanza sugarcane zones, Kenya," Journal of Sustainable Research in Engineering, vol. 4, pp. 30-33, 2014.

[7] L. Janke, S. Weinrich, A. F. Leite et al., "Optimization of semicontinuous anaerobic digestion of sugarcane straw co-digested with filter cake: effects of macronutrients supplementation on conversion kinetics," Bioresource Technology, vol. 245, pp. 35-43, 2017.

[8] L. M. López González, I. Pereda Reyes, and O. Romero Romero, "Anaerobic co-digestion of sugarcane press mud with vinasse on methane yield," Waste Management, vol. 68, pp. 139-145, 2017.

[9] T. C. Sarker, S. M. G. G. Azam, and G. Bonanomi, "Recent advances in sugarcane industry solid by-products 
valorization," Waste and Biomass Valorization, vol. 8, no. 2, pp. 241-266, 2017.

[10] S. Shrestha, X. Fonoll, S. Kumar Khanal, and L. Raskin, "Biological strategies for enhanced hydrolysis of lignocellulosic biomass during anaerobic digestion: current status and future perspectives," Bioresource Technology, vol. 245, pp. 1245-1257, 2017.

[11] J. Mahajan and M. Chopra, "Sugar industry waste to renewable energy," International Journal of Emerging Technologies in Computational and Applied Sciences, vol. 6, pp. 248-250, 2013.

[12] N. B. D. Thi, G. Kumar, and C.-Y. Lin, "An overview of food waste management in developing countries: current status and future perspective," Journal of Environmental Management, vol. 157, pp. 220-229, 2015.

[13] B. A. Parra-Orobio, A. Donoso-Bravo, J. C. Ruiz-Sánchez, K. J. Valencia-Molina, and P. Torres-Lozada, "Effect of inoculum on the anaerobic digestion of food waste accounting for the concentration of trace elements," Waste Management, vol. 71, pp. 342-349, 2018.

[14] W. Schirmer, J. Jucá, A. Schuler, S. Holanda, and L. Jesus, "Methane production in anaerobic digestion of organic waste from Recife (Brazil) landfill: evaluation in refuse of different ages," Brazilian Journal of Chemical Engineering, vol. 31, no. 2, pp. 373-384, 2014.

[15] H. Chen, W. Jiang, Y. Yang, Y. Yang, and X. Man, "State of the art on food waste research: a bibliometrics study from 1997 to 2014," Journal of Cleaner Production, vol. 140, pp. 840-846, 2017.

[16] E. Oviedo-Ocaña, P. Torres-Lozada, L. Marmolejo-Rebellon et al., "A systematic approach to evaluate parameter consistency in the inlet stream of source separated biowaste composting facilities: a case study in Colombia," Waste Management, vol. 62, pp. 24-32, 2017.

[17] F. Raposo, M. A. De La Rubia, V. Fernández-Cegrí, and R. Borja, "Anaerobic digestion of solid organic substrates in batch mode: an overview relating to methane yields and experimental procedures," Renewable and Sustainable Energy Reviews, vol. 16, no. 1, pp. 861-877, 2012.

[18] P. Torres-Lozada, J. S. Díaz-Granados, and B. A. ParraOrobio, "Effects of the incorporation of drinking water sludge on the anaerobic digestion of domestic wastewater sludge for methane production," Water Science and Technology, vol. 72, no. 6, pp. 1016-1021, 2015.

[19] ICONTEC, Norma Técnica Colombiana 5167, Productos para la Industria Agrícola, Productos Orgánicos Usados Como Abonos o Fertilizantes y Enmiendas de Suelo, ICONTEC, Bogotá, D.C, Colombia, 2011.

[20] E. W. Rice, R. B. Baird, A. D. Eaton, and L. S. Clesceri, Eds., Standard Methods for Examination of Water and Wastewater, American Public Health Association, American Water Works Association, Water Environment Federation, Washington, DC, USA, 23rd edition, 2017.

[21] M. Soto, R. Méndez, and J. Lema, "Methanogenic and nonmethanogenic activity tests. Theoretical basis and experimental set up," Water Research, vol. 27, no. 8, pp. 1361-1376, 1993.

[22] B. Parra-Orobio, P. Torres-Lozada, L. Marmolejo-Rebellón et al., "Efecto de la relación sustrato-inóculo sobre el potencial bioquímico de metano de biorresiduos de origen municipal," Ingeniería Investigación y Tecnología, vol. 16, no. 4, pp. 515526, 2015.

[23] C. Pabón, G. Castanares, and J. Van Lier, “An OxiTop protocol for screening plant material for its biochemical methane potential (BMP)," Water Science and Technology, vol. 66, no. 7, pp. 1416-1423, 2012.

[24] L. M. Cárdenas-Cleves, B. A. Parra-Orobio, P. Torres-Lozada, and C. H. Vásquez-Franco, "Perspectives of biochemical methane potential-BMP test for control the anaerobic digestion process of wastes," Revista Investigación, Optimización y Nuevos procesos en Ingeniería, vol. 29, no. 1, pp. 95-108, 2016.

[25] R. A. Labatut, L. T. Angenent, and N. R. Scott, "Biochemical methane potential and biodegradability of complex organic substrates," Bioresource Technology, vol. 102, no. 3, pp. 2255-2264, 2011.

[26] I. Angelidaki, M. Alves, D. Bolzonella et al., "Defining the biomethane potential (BMP) of solid organic wastes and energy crops: a proposed protocol for batch assays," Water Science and Technology, vol. 59, no. 5, pp. 927-934, 2009.

[27] A. Nielfa, R. Cano, and M. Fdz-Polanco, "Theoretical methane production generated by the co-digestion of organic fraction municipal solid waste and biological sludge," Biotechnology Reports, vol. 5, pp. 14-21, 2015.

[28] G. K. Kafle and S. H. Kim, "Anaerobic treatment of apple waste with swine manure for biogas production: batch and continuous operation," Applied Energy, vol. 103, pp. 61-72, 2013.

[29] A. Pérez and P. Torres, "Índices de alcalinidad para el control del tratamiento anaerobio de aguas residuales fácilmente acidificables," Ingeniería y Competitividad, vol. 10, no. 2, pp. 41-52, 2008.

[30] A. Bohórquez, Y. J. Puentes, and J. C. Menjivar, "Evaluación de la calidad del compost producido a partir de subproductos agroindustriales de caña de azúcar," Corpoica Ciencia y Tecnología Agropecuaria, vol. 15, no. 1, pp. 73-81, 2014.

[31] D. H. Lee, S. K. Behera, J. W. Kim, and H.-S. Park, "Methane production potential of leachate generated from Korean food waste recycling facilities: a lab-scale study," Waste Management, vol. 29, no. 2, pp. 876-882, 2009.

[32] R. Zhang, H. M. El-Mashad, K. Hartman et al., "Characterization of food waste as feedstock for anaerobic digestion," Bioresource Technology, vol. 98, no. 4, pp. 929-935, 2007.

[33] F. Lü, L. Hao, M. Zhu, L. Shao, and P. He, "Initiating methanogenesis of vegetable waste at low inoculum-tosubstrate ratio: importance of spatial separation," Bioresource Technology, vol. 105, pp. 169-173, 2012.

[34] B. Sitorus, Sukandar, and S. D. Panjaitan, "Biogas recovery from anaerobic digestion process of mixed fruit-vegetable wastes," Energy Procedia, vol. 32, pp. 176-182, 2013.

[35] Y. Wang, Y. Zhang, J. Wang, and L. Meng, "Effects of volatile fatty acid concentrations on methane yield and methanogenic bacteria," Biomass and Bioenergy, vol. 33, no. 5, pp. 848-853, 2009.

[36] H. Fisgativa, A. Tremier, and P. Dabert, "Characterizing the variability of food waste quality: a need for efficient valorisation through anaerobic digestion," Waste Management, vol. 50, pp. 264-274, 2016.

[37] V. Cabbai, M. Ballico, E. Aneggi, and D. Goi, "BMP tests of source selected OFMSW to evaluate anaerobic codigestion with sewage sludge," Waste Management, vol. 33, no. 7, pp. 1626-1632, 2013.

[38] J. Pagés, I. Pereda, M. Lundin, and I. Sárvári, “Co-digestion of different waste mixtures from agro-industrial activities: kinetic evaluation and synergetic effects," Bioresource Technology, vol. 102, no. 23, pp. 10834-10840, 2011.

[39] L. López, H. Vervaeren, I. Pereda, A. Dumoulin, O. Romero, and J. Dewulf, "Thermo-chemical pre-treatment to solubilize 
and improve anaerobic biodegradability of press mud," Bioresource Technology, vol. 131, pp. 250-257, 2013.

[40] C. Zhang, H. Su, J. Baeyens, and T. Tan, "Reviewing the anaerobic digestion of food waste for biogas production," Renewable and Sustainable Energy Reviews, vol. 38, pp. 383392, 2014.

[41] R. Labatut and C. Gooch, "Monitoring of anaerobic digestion process to optimize performance and prevent system failure," in Proceedings of Got Manure? Enhancing Environmental and Economic Sustainability, pp. 209-225, Liverpool, NY, USA, March 2012.

[42] G. Capson-Tojo, M. Rouez, M. Crest, J.-P. Steyer, J.-P. Delgenès, and R. Escudié, "Food waste valorization via anaerobic processes: a review," Reviews in Environmental Science and Bio/Technology, vol. 15, no. 3, pp. 499-547, 2016. 


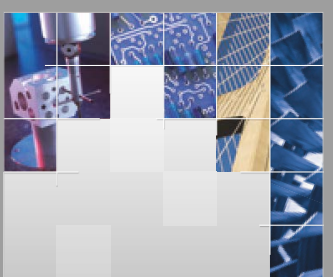

\section{Enfincering}
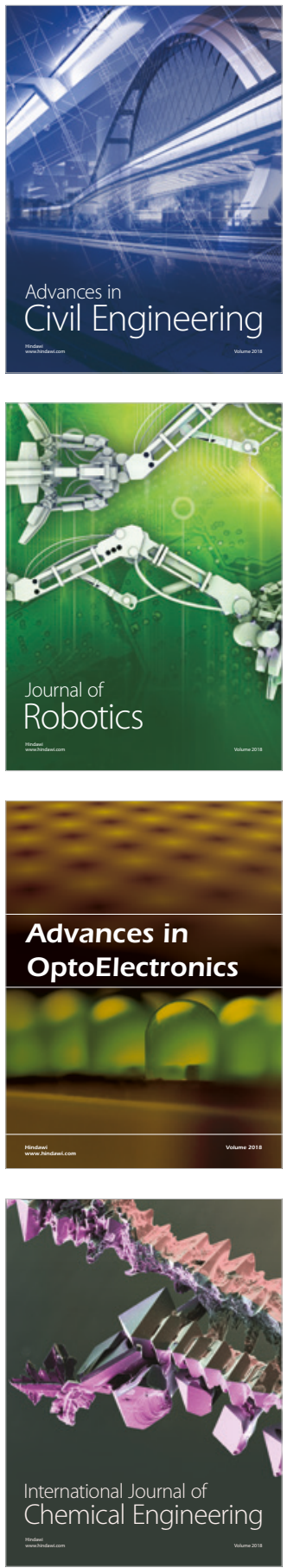

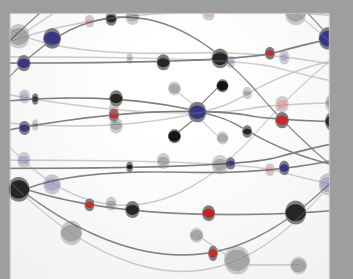

\section{Rotating \\ Machinery}

The Scientific World Journal

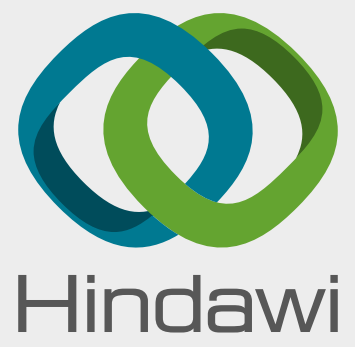

Submit your manuscripts at

www.hindawi.com
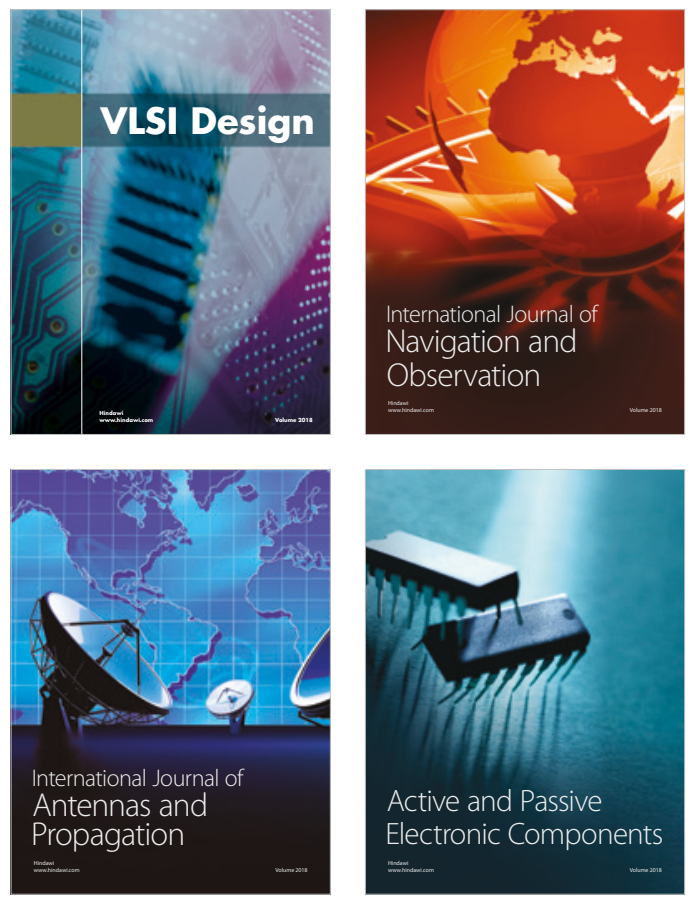
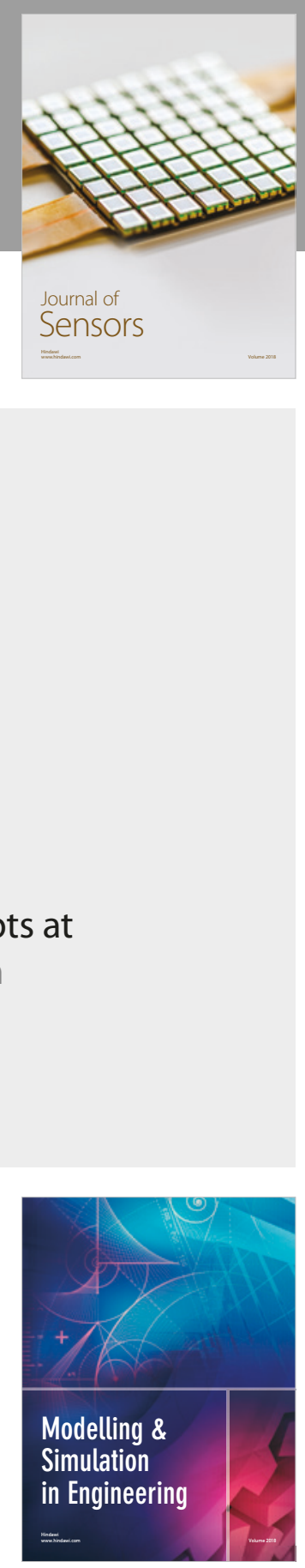

\section{Advances \\ Multimedia}
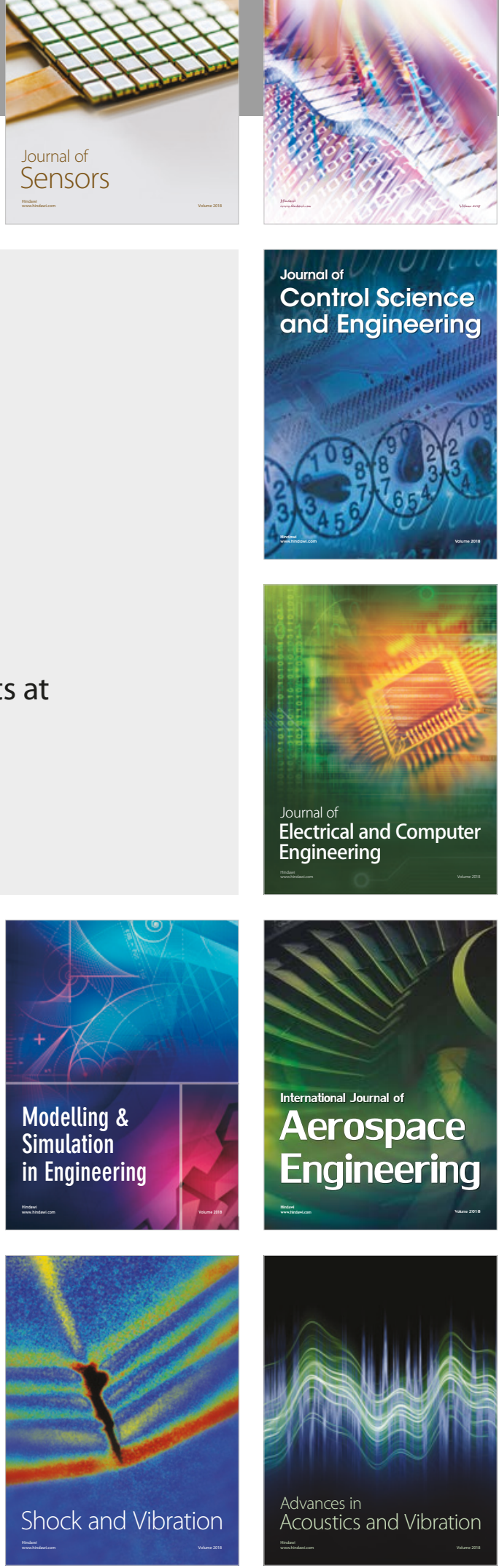